\title{
Neustonic microplastic and zooplankton in the North Western Mediterranean Sea
}

\author{
Amandine Collignon ${ }^{\mathrm{a}, *}$, Jean-Henri Hecq ${ }^{\mathrm{a}, \mathrm{b}}$, François Glagani ${ }^{\mathrm{c}}$, Pierre Voisin ${ }^{\mathrm{d}}$, France Collard ${ }^{\mathrm{a}}$, \\ Anne Goffart ${ }^{\mathrm{a}, \mathrm{b}}$ \\ ${ }^{a}$ MARE Center, Laboratory of Oceanology, University of Liège, Sart Tilman B6c, 4000 Liège, Belgium \\ b STARESO, BP 33, F20260 Calvi, France \\ 'Institut français de recherche pour l'exploitation de la mer (Ifremer), 83507 La Seyne-sur-Mer Cedex, Corse, France \\ 'Association "Expédition MED" - Méditerranée En Danger, 29, rue de Lattre de Tassigny, 56230 Molac, France
}

\section{A R T I C L E I N F O}

\section{Keywords:}

Microplastic particles

Neuston

Mediterranean Sea

\begin{abstract}
A B S T R A C T
Neustonic microplastic and zooplankton abundance was determined in the North Western Mediterranean Sea during a summer cruise between July 9th and August 6th 2010, with a break between July 22 th and 25 th due to a strong wind event. Ninety percent of the 40 stations contained microplastic particles (size $0.3-5 \mathrm{~mm}$ ) of various compositions: e.g., filaments, polystyrene, thin plastic films. An average concentration of 0.116 particles $/ \mathrm{m}^{2}$ was observed. The highest abundances $\left(>0.36\right.$ particles $\left./ \mathrm{m}^{2}\right)$ were observed in shelf stations.

The neustonic plastic particles concentrations were 5 times higher before than after the strong wind event which increased the mixing and the vertical repartition of plastic particles in the upper layers of the water column. The values rise in the same order of magnitude than in the North Pacific Gyre. The average ratio between microplastics and mesozooplankton weights was 0.5 for the whole survey and might induce a potential confusion for zooplankton feeders.
\end{abstract}

(c) 2012 Elsevier Ltd. All rights reserved.

\section{Introduction}

For more than 20 years, plastic debris has been accumulating on the ocean surface. This period corresponds with the growth of plastic-material production (Thompson et al., 2004). Certain constituents of the debris could take more than 500 years to decompose (Gorman, 1993; UNESCO, 1994). Recently, the issue of microplastics (fragments less than $5 \mathrm{~mm}$ ) has attracted increasing attention worldwide. This ubiquitous, persistent debris requires centuries to completely degrade (Derraik, 2002; Hansen, 1990; Goldberg, 1997; Arthur et al., 2009; Barnes et al., 2009; Zarlf et al., 2011).

Microplastics are accumulating at the sea surface, especially within the neustonic habitat (Ryan et al., 2009). This habitat harbors a diverse and specifically adapted zooplankton fauna. Several oceanographic surveys reported high, geographically extensive concentrations of microplastics over oceans and seas: the Northeast Pacific Ocean (Doyle et al., 2011), the central Northern Pacific Ocean (Moore et al., 2001), the Sargassum Sea (Law et al., 2010) and the waters off California (Lattin et al., 2004) all showed high abundances of microplastics at the sea surface.

Microplastics are obviously unsightly. Moreover, it is probable that a wide range of marine organisms are affected by plastic

\footnotetext{
* Corresponding author. Address: University of Liège, Laboratory of Oceanology MARE Research Center, Allée de la Chimie 17, B6C, Institut de Chimie, 4000 Liege (Sart-Tilman), Belgium. Tel.: +32 (0) 496430585.

E-mail address: amandine.collignon@ulg.ac.be (A. Collignon).
}

wastes in the sea. Macrodebris ingestion and entanglement are well documented in sea birds, mammals and turtles and more recently in fishes and invertebrates (e.g., Laist, 1987, 1997; Gramentz, 1988; Weisskopf, 1988; Slip et al., 1990; Moser and Lee, 1992; Shaw and Day, 1994; Goldberg, 1997; Robards et al., 1995; Derraik, 2002; Thompson et al., 2004; Ryan et al., 2009; Boerger et al., 2010; Murray and Cowie, 2011).

The potential confusion of microplastic particles with plankton by filter feeders (the base of the food webs) in the neuston in the North Pacific Gyre has been discussed (Moore et al., 2001). These authors compared the relative abundance of microplastic particles and zooplankton to specifically assess the potential impact of plastic and animal prey on filtering organisms. That study highlighted a relatively high ratio of microplastic abundance to plankton abundance (1:5), which may suggest a potential impact of microdebris on various biota in this region. Previously, no offshore surveys of plastic microfragments in the Mediterranean Sea have been conducted. This paper investigates the ratio of microplastics to zooplankton in neustonic waters of the Northwestern Mediterranean Basin.

\section{Materials and methods}

Forty neustonic samples were collected between July 9th and August 6th, 2010, in the Northwestern Mediterranean Basin, with a break between July 22th and 25th due to a strong wind event. 
The samples were collected at sea. A greater sampling effort was made across the Liguro-Provençal Front (Fig. 1). The stations have been numbered 1-41 (station 8 was excluded due to a sampling problem).

The samples were collected with a manta trawl net lined with $0.333 \mathrm{~mm}$ mesh (Ryan et al., 2009). The size of the rectangular net opening was $0.6 \times 0.2 \mathrm{~m}^{2}$. The trawl sampled the top $10 \mathrm{~cm}$ of the sea surface at an average speed of 2.5 knots for 20 min for each sample. The trawl was towed from a boom installed on the side of the boat to prevent the disturbance of the debris by the bow wave.

Before transferring the samples from the collector to the jar, the net was washed to collect all plankton and debris stuck in the mesh. The samples were then reduced to a volume of $0.20 \mathrm{~L}$ and fixed in $2.5 \%$ formalin.

The samples were placed in graduated cylinders to separate the plastic particles from organic tissue by gravity. The organic tissue sank and was deposited relatively thickly on the bottom of the tubes, whereas the plastic fragments floated. The organic tissue and the plastic were examined, sorted and measured under a binocular microscope. Plastic particles between 0.333 and $5 \mathrm{~mm}$ in size were considered. The abundance of microplastic particles was expressed as number per sea surface area sampled (particles $/ \mathrm{m}^{2}$ ). The microplastic particles were weighed (accuracy: $0.1 \mathrm{mg}$ ) after drying the material for $24 \mathrm{~h}$ at $50^{\circ} \mathrm{C}$.

The zooplankton volume was measured after $24 \mathrm{~h}$ of sedimentation in the graduated cylinders. The dry weight of zooplankton has been estimated according to the ratio of $20.3 \mathrm{mg} / \mathrm{mL}$ obtained experimentally (Leborgne, 1975). The results are expressed in $\mathrm{mg} /$ $\mathrm{m}^{2}$.

\section{Results and discussion}

Ninety percent of the 40 stations contained microplastic particles (size $0.333-5 \mathrm{~mm}$ ) of various types: e.g., filaments, polystyrene, or thin plastic films. Thirty percent of the samples contained more than 0.1 particles $/ \mathrm{m}^{2}$. A total of 4371 microplastic particles, with a total dry weight of $7.9 \mathrm{~g}$, were collected. The mean weight of the microplastics was $1.81 \mathrm{mg}$ per particle, with a mean concentration of $2.02 \mathrm{mg} / \mathrm{m}^{2}$. An average concentration of
Table 1

Synthesis of the survey results (mean microplastic particles and zooplankton).

\begin{tabular}{llll}
\hline & \multicolumn{2}{l}{ Mlcroplastics } & Zooplankton dry weight \\
\cline { 2 - 4 } & particles $/ \mathrm{m}^{2}$ & $\mathrm{mg} / \mathrm{m}^{2}$ & $\mathrm{mg} / \mathrm{m}^{2}$ \\
\hline Mean value & 0.116 & 0.202 & 0.438 \\
Minimal value & 0 & 0 & 0.041 \\
Maximal value & 0.892 & 2.28 & 1.81 \\
East part (mean) & 0.164 & 0.306 & 0.406 \\
Western part (mean) & 0.050 & 0.060 & 0.480 \\
(Storm) & & & \\
\hline
\end{tabular}

0.116 particles $/ \mathrm{m}^{2}$ was observed over the total area investigated (Table 1).

The values of plastic particle abundance fluctuated widely between the stations: 0 particles $/ \mathrm{m}^{2}$ at stations 27-28-29-31 (Occidental part); 0.010 particles $/ \mathrm{m}^{2}$ at station 33 (Marseille); 0.892 particles $/ \mathrm{m}^{2}$ at station 9 (Elba Island) (Figs. 1 and 2). The highest abundances $\left(>0.36\right.$ particles $\left./ \mathrm{m}^{2}\right)$ were observed at the shelf stations (Elba Island and Portofino) associated with the wind direction and in the coastal portion of a transect of 10 stations oriented perpendicular to the Western Corsican coast, where a convergence area is associated with the Liguro-Provençal Front (Goffart et al., 2002). During the first period of the survey (Zone A), $61 \%$ of the stations showed an average abundance of microplastics greater than 0.05 particles $/ \mathrm{m}^{2}$. This percentage decreased to $19 \%$ for the stations sampled in the second period of the survey (Zone B). This difference could be explained by the impact of the velocity and direction of the wind (Fig. 3). The microplastic particle concentrations measured during the first part of the survey (mean: $0.306 \mathrm{mg} / \mathrm{m}^{2}$; stations 1-24, Eastern area) before the strong wind event were 5 times higher than those measured during the second part of the survey (mean: $0.060 \mathrm{mg} / \mathrm{m}^{2}$; stations $25-41$, Western area). This significant difference may be explained by the drastic changes in wind conditions (wind force 5-6 B) during the second part of the survey. The resulting wind stress increased the mixing and the vertical redistribution of the plastic particles in the upper layers of the water column.

The mean abundance of microplastics estimated here is of the same order of magnitude as that found for the North Pacific Gyre (0.334 particles $/ \mathrm{m}^{2}$, Moore et al., 2001). However, the present

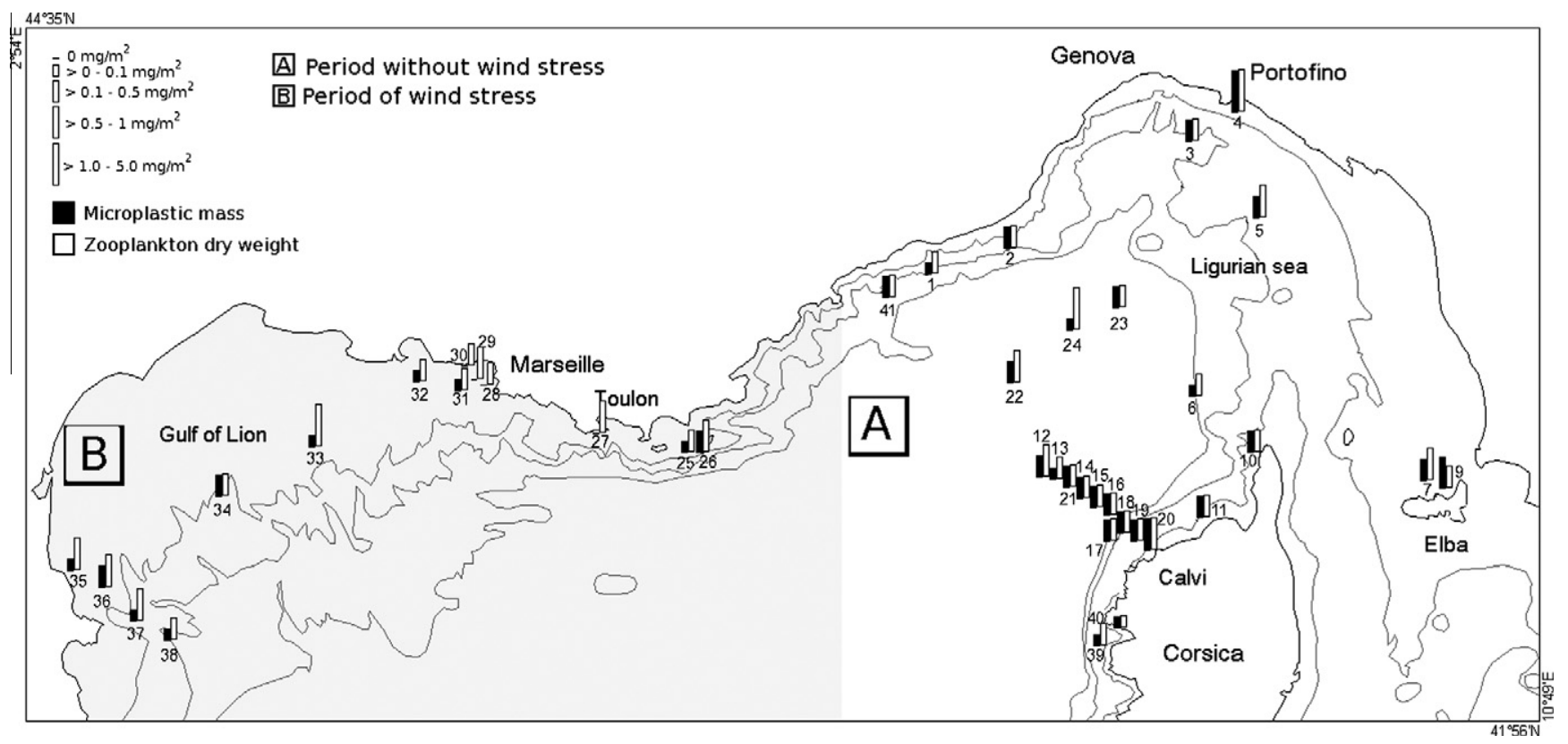

Fig. 1. Distribution of the zooplankton dry weight and the mass of the microplastic particles $\left(\mathrm{mg} / \mathrm{m}^{2}\right)$ present in the neuston samples collected in the two areas. 


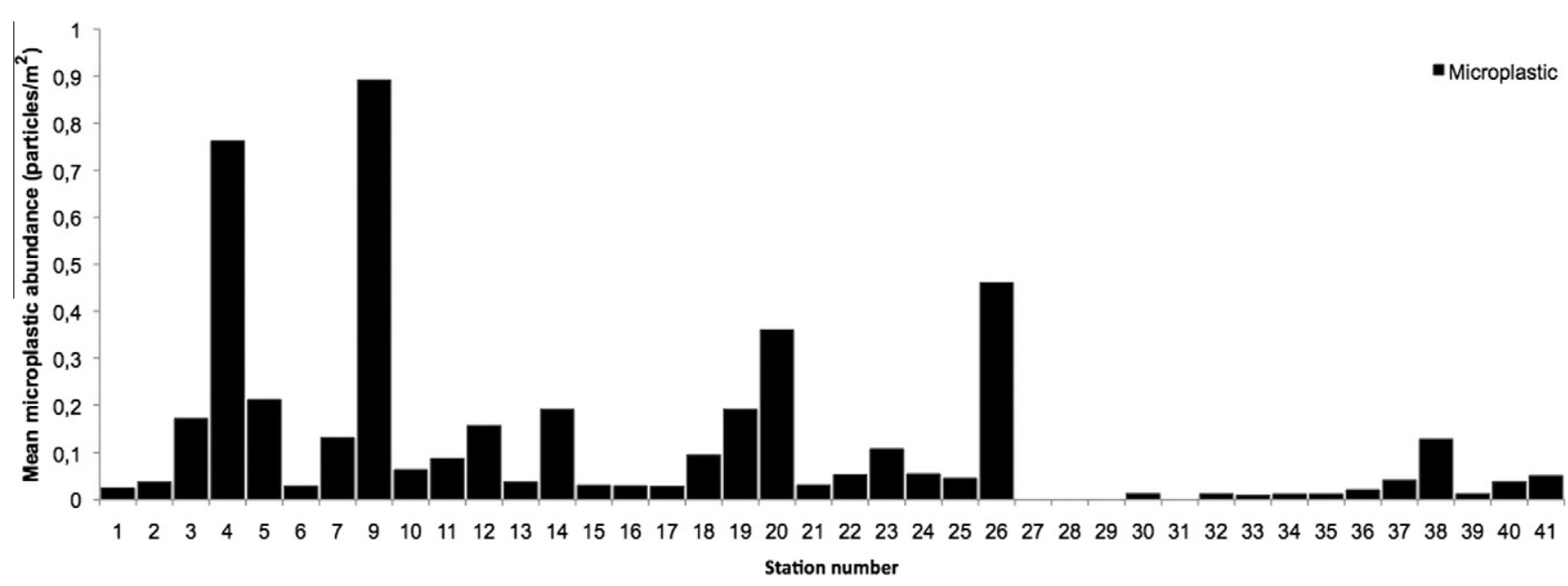

Fig. 2. Amount of plastic (particles $/ \mathrm{m}^{2}$ ) at the different stations.

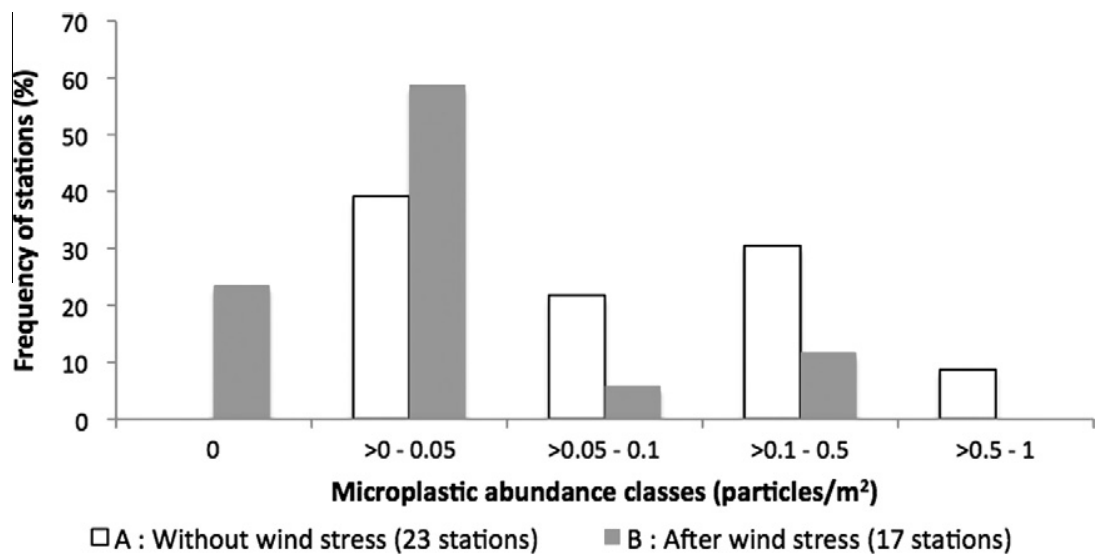

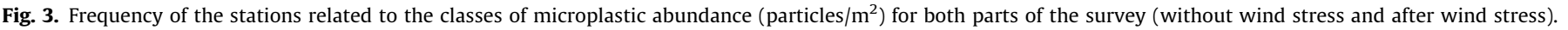

values are significantly higher than those obtained from 20 years of monitoring in the Caribbean Sea $\left(0.001\right.$ particles $\left./ \mathrm{m}^{2}\right)$ and in the Gulf of Maine $\left(0.002\right.$ particles $\left./ \mathrm{m}^{2}\right)$ as well as in the North Atlantic Gyre $\left(0.020\right.$ particles $\left./ \mathrm{m}^{2}\right)$, where the Subtropical Convergence is responsible for the accumulation of floating particles (Law et al., 2010) (Table 2). It is probable that the high microdebris abundances obtained in this assessment are due to the specific configuration of the semi-enclosed Mediterranean system. The Mediterranean is subject to permanent waste inputs, such as that occurring on the continental shelf of the Golf du Lion. This area is affected by the outflow from the Rhone River and by NW winds (the Mistral and Tramontane winds) that flush wastes towards offshore waters (Galgani et al., 2000).

This first set of results suggests that the mean weight of particles was smaller in this study $(1.81 \mathrm{mg})$ than in the North Pacific Gyre $(14.97 \mathrm{mg})$. In the North Pacific Gyre, microplastics derived from fishing or nautical activities were primarily encountered (Moore et al., 2002). In contrast, smaller material flushed at sea from continental output was recorded in Northwestern Mediterranean coastal waters, where most of the particles (69\%) were smaller than $2 \mathrm{~mm}$. This difference could be due to more intense mechanical action, a longer residence time (older debris) or more substantial fouling involving larger debris.

The zooplankton weight fluctuated between $0.041 \mathrm{mg} / \mathrm{m}^{2}$ and $1.81 \mathrm{mg} / \mathrm{m}^{2}$, and the average zooplankton weight was similar in the western $\left(0.480 \mathrm{mg} / \mathrm{m}^{2}\right)$ and the eastern $\left(0.406 \mathrm{mg} / \mathrm{m}^{2}\right)$ parts of the area investigated (Table 1 ). The zooplankton, unlike the microplastics, is relatively unaffected by wind stress and mixing and can swim to maintain its distribution in the neustonic layers. The average ratio between the microplastic and mesozooplankton weights was 0.5 for the whole survey and is relatively low compared to other regions (Moore et al., 2001).

Few studies have addressed the impact of microplastics on filter-feeding organisms or other planktivorous animals. Microplastics in great abundance within the photic zone could both compete with and threaten the plankton. The neustonic habitat is a feeding area for various organisms that capture plankton actively or through water filtering. Laboratory experiments demonstrate that amphipods, barnacles and worms could ingest microplastics. In these experiments, plastic fragments were found in the stomachs of the experimental animals (Thompson et al., 2004). Salps can also be affected (Moore et al., 2001) because they cannot differentiate plastic fragments from plankton. Microplastics were found in the guts of certain planktivorous fishes (Myctophidae, Stomiidae and Scomberesocidae) in the North Pacific Gyre, with an average of 2.1 pieces per fish (Boerger et al., 2010). In the Mediterranean during the present survey, plastic microdebris were found in the stomachs of myctophids (Myctophum punctatum) (Laboratoire Biodoxis/Foundation CIMA, unpublished data).

In conclusion, many aspects of the distribution and impact on the environment of microplastics require further study. The physiological effects related to plastic ingestion are poorly understood, as are the implications of plastic ingestion for food chains. Microplastics can be a significant carrier of lipophilic chemicals (POPs) 
Table 2

Comparison between this study and other sampled areas (Average debris - mean mass).

\begin{tabular}{|c|c|c|c|}
\hline & \multicolumn{2}{|c|}{ Mean microplastics } & \multirow[t]{2}{*}{ References } \\
\hline & particles $/ \mathrm{m}^{3}$ & $\mathrm{mg} / \mathrm{m}^{3}$ & \\
\hline USA north east (coastal waters) & $0.01-2.6$ & & Carpenter et al. (1972) \\
\hline North Pacific Gyre study & 2.23 & 34 & Moore et al. (2001) \\
\hline San Gabriel River Study // Southern California's coastal waters & 7.25 & 2 & Moore et al. (2002) \\
\hline Southern California - Santa Monica Bay & 3.92 & 3 & Lattin et al. (2004) \\
\hline North Pacific offshore, surface & $0.43-2.23$ & & Moore et al. (2005) \\
\hline North Pacific, inshore, surface & $5.0-7.25$ & & Moore et al. (2005) \\
\hline North Pacific, offshore, subsurface & 0.017 & - & Moore et al. (2005) \\
\hline Northeast Pacific ocean & $0.004-0.19$ & $0.024-0.202$ & Doyle et al. (2011) \\
\hline Atlantic & $<0.1$ & - & Doyle et al. (2011) \\
\hline North Pacific Central Gyre & 0.334 & 511 & Moore et al. (2001) \\
\hline Atlantic & 0.020 & - & Law et al. (2010) \\
\hline Caraibes & 0.001 & - & Law et al. (2010) \\
\hline Golf of Maine & 0.001 & - & Law et al. (2010) \\
\hline San Gabriel River & 0.002 & - & Moore et al. (2002) \\
\hline NW Mediterranean & 0.116 & 0.202 & This study \\
\hline
\end{tabular}

and a source of pollutants such as polyethylene, polypropylene, and polyphenols that can potentially affect organisms (Teuten et al., 2007). Additional studies are required to assess the transfer mechanisms of those compounds from plastic to zooplanktonic organisms at the base of the food chain. Moreover, plastic fragments can act as substrates to allow the transport of alien species (Barnes, 2002; Aliani and Molcard, 2003; Gregory, 2009).

The present study provides an initial insight into microplastic pollution in the Mediterranean Sea by reporting the concentration levels and spatial distribution of microplastics in the area surveyed.

\section{Acknowledgements}

This work was supported by the Fonds de la Recherche Scientifique (F.R.S.-FNRS) and the Fonds pour la formation à la Recherche dans l'Industrie et dans l'Agriculture (FRIA). J.-H. Hecq is senior research associate, FRS. We thank Bruno Dumontet, director of the MED program (Mediterranée En Danger), and the crew of the Halifax.

\section{References}

Aliani, S., Molcard, A., 2003. Hitch-hiking on floating debris: a contribution from a macrobenthic species in the Western Mediterranean. Hydrobiology 503, 59-67.

Arthur, C., Baker, J., Bamford, H. (Eds.), 2009. Proceedings of the International Research Workshop on the Occurrence, Effects and Fate of Microplastic Marine Debris, NOAA Technical Memorandum NOS-OR \& R-30.NOAA, Silver Spring, September 9-11, 2008, 530.

Barnes, D.K.A., 2002. Invasions by marine life on plastic debris. Nature 416, $808-$ 809.

Barnes, D.K.A., Galgani, F., Thompson, R.C., Barlaz, M., 2009. Accumulation and fragmentation of plastic debris in global environments. Phil. Trans. R. Soc. B 364 (1526), 1985-1998.

Boerger, C., Lattin, G., Moore, S.L., Moore, C.J., 2010. Plastic ingestion by planktivorous fishes in the North Pacific Central Gyre. Mar. Poll. Bull. 60 (12), 2275-2278.

Carpenter, E.J., Miklas, H.P., Peck, B.B., Anderson, S.J., Harvey, G.R., 1972. Polystyrene spherules in coastal waters. Science (Wash.) 178, 749-750.

Derraik, J.G.B., 2002. The pollution of the marine environment by plastic debris: a review. Mar. Pollut. Bull. 44, 842-852.

Doyle, M., Watson, W., Bowlin, N., Sheavly, S., 2011. Plastic particles in coastal pelagic ecosystems of the Northeast Pacific ocean. Mar. Environ. Res. 71, 41-52.

Galgani, F., Leaute, J.P., Moguedet, P., Souplet, A., Verin, Y., Carpentier, A., Goraguer, H., Latrouite, D., Andral, B., Cadiou, Y., Mahe, J.C., Nerisson, P., 2000. Litter on the sea floor along European Coasts. Mar. Poll. Bull. 40 (6), 516-527.

Goffart, A., Hecq, J.-H., Legendre, L., 2002. Changes in the development of the winter-spring phytoplankton bloom in the Bay of Calvi (NW Mediterranean) over the last two decades: a response to changing climate? Mar. Ecol. Prog. Ser. 236, 45-60.

Goldberg, E.D., 1997. Plasticizing the seafloor: an overview. Environ. Technol. 18, 195-202.
Gorman, M., 1993. Environmental Hazards: Marine Pollution. ABC - CLIO Inc., Santa Barbara, $252 \mathrm{p}$

Gramentz, D., 1988. Involvement of loggerhead turtle with the plastic, metal, and hydrocarbon pollution in the Central Mediterranean. Mar. Pollut. Bull. 19, 1113.

Gregory, M., 2009. Environmental implications of plastic debris in marine settings: entanglement, ingestion, smothering, hangers-on, hitch-hiking and alien invasions. Philos. Trans. R. Soc. B. 364, 2013-2025.

Hansen, J., 1990. Draft position statement on plastic debris in marine environments. Fisheries 15, 16-17.

Laist, D.W., 1987. Overview of the biological effects of lost and discarded plastic debris in the marine environment. Mar. Pollut. Bull. 18, 319-326.

Laist, D.W., 1997. Impacts of marine debris: entanglement of marine life in marine debris including a comprehensive list of species with entanglement and ingestion records. In: Coe, J.M., Rogers, D.B. (Eds.), Marine Debris - Sources, Impacts and Solutions. Springer-Verlag, NewYork, pp. 99-139.

Lattin, G.L., Moore, C.J., Zellers, A.F., Moore, S.L., Weisberg, S.B., 2004. A comparison of neustonic plastic and zooplankton at different depths near the southern California shore. Mar. Pollut. Bull. 49, 291-294.

Law, K., Morét-Ferguson, S., Maximenko, N., Proskurowski, G., Peacock, E., Hafner, J. Reddy, C., 2010. Plastic accumulation in the North Atlantic Subtropical Gyre. Science 329, 1185-1188.

Leborgne, R., 1975. Equivalences entre les mesures de biovolumes, poids sec, poids sec sans cendre, carbone, azote et phosophore du mésozooplancton de l'Atlantique Tropical, Cah. O.R.S.T.O.M.. Sér. Océanogr. 13 (3), 179-196.

Moore, C.J., Moore, S.L., Leecaster, M.K., Weisberg, S.B., 2001. A comparison of plastic and plankton in the North Pacific Central Gyre. Mar. Pollut. Bull. 42 (12), 1297 1300 .

Moore, C.J., Moore, S.L., Weisberg S.B., Lattin, G.L, Zellers, A.F, 2002. A comparison of neustonic plastic and zooplankton abundance in southern California's coastal waters. Mar. Pollut. Bull. 44, 1035-1038.

Moore, C.J., Lattin, G.L., Zellers, A.F., 2005. Density of Plastic Particles Found in Zooplankton Trawls From Coastal Waters of California to the North Pacific Central Gyre, The Plastic Debris Rivers to Sea Conference. Redondo Beach California, USA.

Moser, M.L., Lee, D.S., 1992. A fourteen-year survey of plastic ingestion by western North Atlantic seabirds. Colo. Waterbirds 15, 83-94.

Murray, F., Cowie, F.R., 2011. Plastic contamination in the decapod crustacean Nephropsnorvegicus (Linnaeus, 1758). Mar. Poll. Bull. 62 (6), 1207-1217.

Robards, M.D., Piatt, J.F., Wohl, K.D., 1995. Increasing frequency of plastic particles ingested by seabirds in the subarctic North Pacific. Mar. Pollut. Bull. 30, 151157.

Ryan, P.G., Moore, C.J., Van Franeker, J.A., Moloney, C.L., 2009. Monitoring the abundance of plastic debris in the marine environment. Philos. Trans. R. Soc. B 364, 1999-2012.

Shaw, D.G., Day, R.H., 1994. Colour- and form-dependent loss of plastic microdebris from the North Pacific Ocean. Mar. Pollut. Bull. 28, 39-43.

Slip, D.J., Green, K., Woehler, E.J., 1990. Ingestion of anthropogenic articles by seabirds at Macquarie Island. Mar. Ornithol. 18, 74-77.

Teuten, E.L., Rowland, S.J., Galloway, T.S., Thompson, R.C., 2007. Potential for plastics to transport hydrophobic contaminants. Environ. Sci. Technol. 41, 7759-7764.

Thompson, R.C., Olsen, Y., Mitchell, R.P., Davis, A., Rowland, S.J., John, A.W.G. McGonigle, D., Russell, A.E., 2004. Lost at sea: where is all the plastic? Science $304,838$.

UNESCO, 1994. Marine Debris: Solid Waste Management Action Plan for the Wider Caribbean, IOC Technical Series 41, Paris.

Weisskopf, M., 1988. Plastic reaps a grim harvest in the oceans of the world (plastic trash kills and maims marine life). Smithsonian 18, 58 .

Zarlf, C., Fleet, D., Fries, E., Galgani, F., Gerdts, G., Hanke, G., 2011. Microplastics in oceans. Mar. Pollut. Bull. 62 (8), 1589-1591. 